\title{
BIOREMEDIATION TECHNIQUES
}

\author{
ON \\ CRUDE OIL CONTAMINATED SOILS IN OHIO
}

Introduction DE-FG22-95MT95018-01

The purpose of this study is to define the optimum limits of chemical and physical conditions that reduce soil salinity and maximize indigenous aerobic microbiological populations in the bioremediation of oil field waste solids. Specifically, the study centers around treatment of surface contained oily waste having low density and limited solubility in water. Successful remediation is defined by total petroleum hydrocarbon $(\mathrm{TPH})$ reduction to $1 \%$ and no hydrocarbon or salinity impact on ground water resources.

The Department of Energy, the United States Environmental Protection Agency and the Interstate Oil and Gas Compact Commission have encouraged oil and gas producing states to identify and develop improved methods such as this to reduce, recycle or treat solid waste generated with the exploration and development of domestic petroleum resources (IOGCC, 1995). With encouragement and funding assistance through the Department of Energy, Ohio is developing these bioremediation practices to protect soil and water resources. Ohio produced 8,300,000 barrels of crude oil in 1996 from wells operated by 4310 registered owners (ODNR, 1996). Good well site housekeeping can minimize spills, however accidental spills inevitably occur with oil production of this magnitude. Development of sound environmental and economical clean-up procedures is essential. 


\section{Discussion}

The study site is located in section four of Smith Township, Mahoning County (figure 1). This site, situated within the glaciated Appalachian Plateau province of Ohio, is characterized by gently rolling topography with Kent ground moraine overlying Pennsylvania sandstone bedrock. Soils are classified as Mahoning Silt Loam (USDA, 1971). Land surface is nearly flat and moderately well drained.

An area 6 meters $(\mathrm{m})$ (20 feet (ft.) ) wide by $33.5 \mathrm{~m}(110 \mathrm{ft}$.) long was plowed to a depth of approximately 20 centimeters (cm) (8 inches (in.)) on July 3, 1995. The site was divided into twenty-two plots $3 \mathrm{~m}$ (10 ft.) square. The plots were arranged and numbered as shown in figure 2a. On August 17, 1995, Plots 1,3,5,7,9 and 11 received 159 liters (1) (42 gallons (gals.) ) of Corning grade crude oil having an American Petroleum Institute (API) gravity of 34. Plots 2,4,6,8,10 and 12 were treated with an equal amount of Pennsylvania grade crude oil with an API gravity of 43. Crude oil saturation depth was less than $15 \mathrm{~cm}$. (6 in.) in all plots. The two barrels totaling 370 l. (84 gal.), simulating a typical oil release or spill were immediately and individually rotary tilled into the top $15 \mathrm{~cm}$. (6 in.) of soil.

The remaining plots, 13 through 22, received 159 1. (42 gals.) of Pennsylvania grade crude oil and 4771 (126 gals.) of Clinton formation brine. Chloride concentration of the brine was 160,000 milligrams/liter (mg/l). Again, materials were immediately incorporated into the top $15 \mathrm{~cm}$. (6 in.) of soil. A composite control sample was then collected from sites 1,3,5,7,9 and 11 and another from sites 2,4,6,8,10 and 12. Results are presented in Appendix 1.

Rotary tilling (tilling) was accomplished using a model 340 MTD chain drive 5hp front tine tilling machine. Each pass included a one half overlap to the previous pass. The tiller was allowed to run at a stand still at the edge of each plot before proceeding, to minimize cross-plot contamination. With each till event throughout the study, amendments were thoroughly combined with the soil and the soil pulverized for good aeration.

Variables within the plots included delay between periods of aeration, periods of nutrient application and addition of organic bulk. These variables were applied to the plots on which two grades of crude oil and crude oil with brine had been incorporated.

In overview the site initially prepared on August 17,1995, was treated and monitored until October 26,1995 , when soil temperatures dropped to $8^{\circ}$ centigrade $\left(\mathrm{C}^{\circ}\right)\left(45.7^{\circ}\right.$ Fahrenheit $\left(\mathrm{F}^{\circ}\right)$ ). During this season the plots were aerated each week or monthly as the schedule required (figure 2a) and weather permitted. A total of four weekly tillages were completed from August 17 to September 24, 1995. Nutrients were added to the appropriate sites (figure 2a) on August 
17 and September 
Figure 1

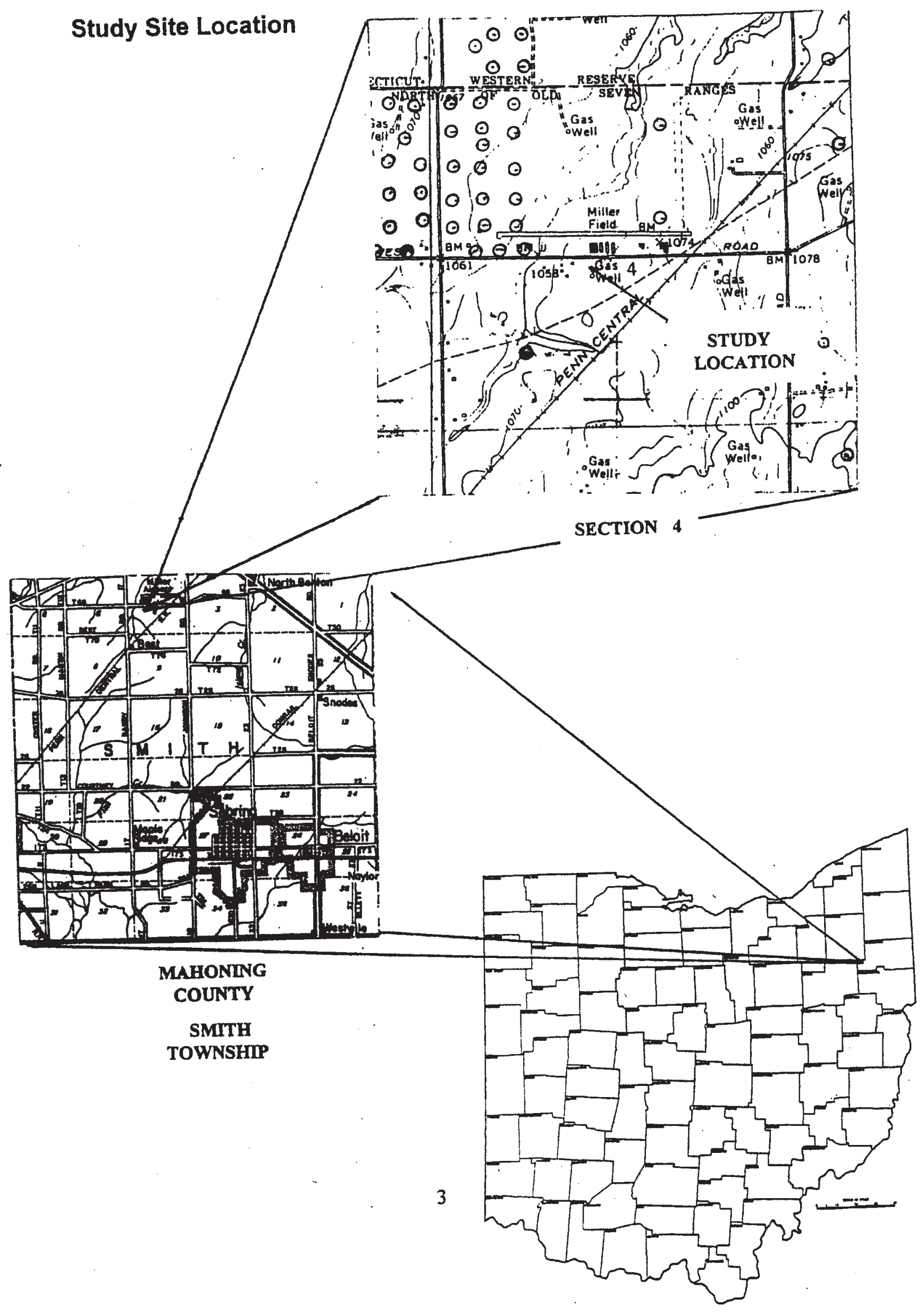


Figure 2a

Initial Arrangement of Remediation Plots and Variables

Crude Oil Contaminated Area

\begin{tabular}{|l|c|c|c|c|c|c|}
\hline $\begin{array}{l}\text { Pennsylvania Grade Crude Oil } \\
\text { Plots 2,4,6,8,10\&12 }\end{array}$ & $\begin{array}{c}2 \text { aw } \\
\mathrm{nm} \\
\text { oy }\end{array}$ & $\begin{array}{c}4 \mathrm{aw} \\
\mathrm{nm} \\
\text { on }\end{array}$ & $\begin{array}{c}6 \text { aw } \\
\mathrm{ni} \\
\text { oy }\end{array}$ & $\begin{array}{c}8 \mathrm{aw} \\
\mathrm{ni} \\
\text { on }\end{array}$ & $\begin{array}{c}10 \mathrm{aw} \\
\mathrm{nm} \\
\text { oy }\end{array}$ & $\begin{array}{c}12 \mathrm{am} \\
\mathrm{nm} \\
\text { on }\end{array}$ \\
\hline Corning Grade Crude Oil & 1 aw \\
Plots 1,3,5,7,9\&11 & $\begin{array}{c}3 \mathrm{aw} \\
\mathrm{nm}\end{array}$ & $\begin{array}{c}\mathrm{nm} \\
\text { oy }\end{array}$ & $\begin{array}{c}\mathrm{aw} \\
\mathrm{ni} \\
\text { oy }\end{array}$ & $\begin{array}{c}7 \mathrm{aw} \\
\mathrm{ni} \\
\text { on }\end{array}$ & $\begin{array}{c}9 \mathrm{aw} \\
\mathrm{nm} \\
\text { oy }\end{array}$ & $\begin{array}{c}11 \mathrm{am} \\
\mathrm{nm} \\
\text { on }\end{array}$ \\
\hline
\end{tabular}

Pennsytvania Crude Oil and Clinton Brine Contaminated Area

\begin{tabular}{|l|c|c|c|c|c|}
\hline $\begin{array}{l}\text { High Calcium } \\
\text { Amendment }\end{array}$ & $\begin{array}{c}14 \mathrm{aw} \\
\mathrm{ni} \\
\text { oy }\end{array}$ & $\begin{array}{c}16 \mathrm{aw} \\
\mathrm{nm} \\
\text { oy }\end{array}$ & $\begin{array}{c}18 \mathrm{am} \\
\mathrm{ni} \\
\text { oy }\end{array}$ & $\begin{array}{c}20 \mathrm{am} \\
\mathrm{ni} \\
\text { on }\end{array}$ & $\begin{array}{c}22 \mathrm{am} \\
\mathrm{nm} \\
\text { on }\end{array}$ \\
\hline $\begin{array}{l}\text { Low Calcium } \\
\text { Amendment }\end{array}$ & $\begin{array}{c}13 \mathrm{aw} \\
\mathrm{ni} \\
\text { oy }\end{array}$ & $\begin{array}{c}15 \mathrm{aw} \\
\mathrm{nm} \\
\text { oy }\end{array}$ & $\begin{array}{c}17 \mathrm{am} \\
\mathrm{ni} \\
\text { oy }\end{array}$ & $\begin{array}{c}19 \mathrm{am} \\
\mathrm{ni} \\
\text { on }\end{array}$ & $\begin{array}{c}21 \mathrm{am} \\
\mathrm{nm} \\
\text { on }\end{array}$ \\
\hline
\end{tabular}

Figure 2b

Revised Arrangement of Remediation Plots and Variables

Crude Oil Contaminated Area

\begin{tabular}{|l|c|c|c|c|c|c|}
\hline $\begin{array}{l}\text { Pennsylvania Grade Crude Oil } \\
\text { Plots 2,4,6,8,10\&12 }\end{array}$ & $\begin{array}{c}2 \mathrm{aw} \\
\mathrm{nm} \\
\text { oy }\end{array}$ & $\begin{array}{c}4 \mathrm{aw} \\
\mathrm{nm} \\
\text { on }\end{array}$ & $\begin{array}{c}6 \mathrm{aw} \\
\mathrm{ni} \\
\text { oy }\end{array}$ & $\begin{array}{c}8 \mathrm{aw} \\
\mathrm{ni} \\
\text { oy }\end{array}$ & $\begin{array}{c}10 \mathrm{am} \\
\mathrm{nm} \\
\text { oy }\end{array}$ & $\begin{array}{c}12 \mathrm{am} \\
\mathrm{nm} \\
\text { on }\end{array}$ \\
\hline $\begin{array}{l}\text { Corning Grade Crude Oil } \\
\text { Plots 1,3,5,7,9811 }\end{array}$ & $\begin{array}{c}1 \mathrm{aw} \\
\mathrm{nm} \\
\text { oy }\end{array}$ & $\begin{array}{c}3 \mathrm{aw} \\
\mathrm{nm} \\
\text { on }\end{array}$ & $\begin{array}{c}5 \mathrm{aw} \\
\mathrm{ni} \\
\text { oy }\end{array}$ & $\begin{array}{c}7 \mathrm{aw} \\
\mathrm{ni} \\
\text { on }\end{array}$ & $\begin{array}{c}9 \mathrm{am} \\
\mathrm{nm} \\
\text { on }\end{array}$ & $\begin{array}{c}11 \mathrm{am} \\
\mathrm{nm} \\
\text { on }\end{array}$ \\
\hline
\end{tabular}

Pennsylvania Crude Oil and Clinton Brine Contaminated Area

\begin{tabular}{|l|c|c|c|}
\hline $\begin{array}{l}\text { High Calcium } \\
\text { Amendment }\end{array}$ & $\begin{array}{c}16 \mathrm{aw} \\
\mathrm{nm} \\
\text { oy }\end{array}$ & $\begin{array}{c}18 \mathrm{aw} \\
\mathrm{nm} \\
\text { on }\end{array}$ & $\begin{array}{c}20 \mathrm{aw} \\
\mathrm{nm} \\
\text { on }\end{array}$ \\
\hline $\begin{array}{l}\text { Low Calcium } \\
\text { Amendment }\end{array}$ & $\begin{array}{c}15 \mathrm{aw} \\
\mathrm{nm} \\
\text { oy }\end{array}$ & $\begin{array}{c}17 \mathrm{aw} \\
\mathrm{nm} \\
\text { oy }\end{array}$ & $\begin{array}{c}19 \mathrm{aw} \\
\mathrm{nm} \\
\text { on }\end{array}$ \\
\hline
\end{tabular}

Legend of Variables on Each Plot aeration weekly aw aeration monthly am nutrients initially only ni nutrients monthly $\quad \mathrm{nm}$ organic bulk added oy orgainic bulk not added on 
14, 1995. Granular gypsum was applied only on August 24, 1995. Application rates were arbitrarily selected and adjusted based on analytical results. Samples were collected on August 17, September 14, and October 12, 1995.

Treatment of the plots began on August 17,1995, with an application of triple-14 granular fertilizer applied to the 22 plots at a rate of 0.81 kilograms/square meter $\left(\mathrm{Kg} / \mathrm{m}^{2}\right)(1.5$ pounds/square yard $\left.\left(\mathrm{lb}_{\mathrm{b}} \mathrm{yd}^{2}\right)\right)$. Triple-14 fertilizer was selected for the relatively high nitrogen content and this fertilizer is commonly available at feed and garden supply stores. Plots were again tilled to incorporate these materials to the depth of $15 \mathrm{~cm}$ (6 in.).

On August 24, 1995, a mixture of partially decomposed sawdust and horse manure was dry applied to test plots 1,2,5,6,9,10,13,14,15,16,17 and 18 (figure 2a). Approximately 6.8 cubic meters $\left(\mathrm{m}^{3}\right)\left(240\right.$ cubic feet $\left.\left(\mathrm{ft.}^{3}\right)\right)$ of manure was applied once, covering the selected plots to a depth of $2.54 \mathrm{~cm}$ (1.0 in.) or deeper. Granular gypsum was applied to all 22 plots at a rate of $0.54 \mathrm{~kg} / \mathrm{m}^{2}\left(1.0 \mathrm{lb} / \mathrm{yd}^{2}\right)$ and all materials were then tilled into the soil.

Plots were tilled on August 13, and September 7, 1995. Field measurements of soil moisture and $\mathrm{pH}$ were obtained from each plot using a Kelway Soil Tester. Measurements were collected at a depth of $5.08 \mathrm{~cm}$ (2 in.) (Appendix 2) on September 7, 1995, September 28, 1995 and July 8, 1996.

Weekly plots were tilled on September 14, 1995 prior to collection of 22 composite samples. (Appendix 3) Composite samples consisted of 5 equally spaced collection sites within each plot. Four split samples were divided from the composite samples of plots 2,7,16 and 19 (figure 2a ). The 22 samples were analyzed at a contract laboratory. Four split samples were analyzed at an independent laboratory for quality control (Appendix 4). Following sample collection, triple-14 fertilizer was added at a rate of $0.4 \mathrm{~kg} / \mathrm{m}^{2}\left(0.75 \mathrm{lb} / \mathrm{yd}^{2}\right)$ to the 12 plots (figure 2a) receiving monthly nutrients. All 22 plots were then tilled to mix nutrients and aerate.

Plots were tilled two additional times prior to October 5, 1995. At this time weather conditions became too wet to continue working the soil. The second composite sample collection of all 22 plots was conducted on October 12, 1995(Appendix 5). Two additional samples were collected at depths of 46 to $61 \mathrm{~cm}$ (18 to 24 in.) in plots 3 and 20, to identify any possible deep leaching of hydrocarbons (Appendix 6). 
Study of sample results from the first quarter of project work resulted in some changes to the study methods. The variable of weekly versus monthly tilling provided no significant change in results therefore a weekly only tilling schedule was adopted for all plots. Nutrient application as a variable was discontinued and nutrients were applied monthly for all plots. To reduce cost and increase sampling frequency within each plot the number of plots sampled was reduced from

22 to 18 (figure $2 b$ ).

An unseasonably cold and wet spring and early summer resulted in high soil moisture and a delay in work on the remediation site until June 17, 1996. Tilling re-established the depth of aeration to $15.2 \mathrm{~cm}$. (6in.) and incorporated a 1 meter (3.28 ft.) high spring weed growth on the 18 plots of the revised study area. A second and third tilling on this date incorporated pulverized agricultural lime that was spread at a rate of $1.1 \mathrm{~kg} / \mathrm{m}^{2}\left(.25 \mathrm{lb} / \mathrm{ft}^{2}\right)$ over all 18 plots in an attempt to increase $\mathrm{pH}$. This was the only time additional lime was added but nutrients were added on July 8 and August 7, 1996. Samples were collected on August 7, and September 13, 1996. (Appendix 7,8) Triple-14 fertilizer was spread at the rate of $1.22 \mathrm{~kg} / \mathrm{m}^{2}\left(2.25 \mathrm{lbs} / \mathrm{yd}^{2}\right)$ on all 18 plots and tilled into the top $15 \mathrm{~cm}$ (6 in.) on July 8, 1996.

On August 7, 1996, 36 samples were collected from the 18 active plots. Each plot was divided in half. Within each half plot, five equally spaced samples were collected and combined to create a single composite sample. The alternate half plot was sampled in a like manner. Sampling of 17 remaining plots lead to 36 composite samples. Results from these samples are presented in appendix 5. Triple-14 fertilizer was spread on the 18 plots at a rate of $0.15 \mathrm{~kg} / \mathrm{m}^{2}\left(0.28 \mathrm{lbs} / \mathrm{yd}^{2}\right)$. Plots were tilled to mix nutrients into the soil. Closure samples were collected on September 13, 1996, after results of TPH analyses from the August samples were reviewed (Appendix 8). On October 22, 1996, restoration of the site and closure of the study was completed with planting of grass seed and spreading of mulch. 


\section{Results}

Many chemical and physical parameters were tested through the course of this bioremediation study. Certain parameters were analyzed in all five sampling episodes, others were not. Variations in sampling and analyses will be discussed in detail. Sample analyses and field measurements are presented in Appendices 1 through 6.

The five most critical factors affecting the successful completion of any bioremediation project include; soil moisture, soil temperature, oxygen, $\mathrm{pH}$, and available nutrients. Chemical analyses or measurements, as they relate to these factors, will be discussed. Soil moisture, soil temperature and oxygen, although very important to the bioremediation process, were very simple factors to assess or control.

\section{Soil Moisture:}

Published articles and studies suggest optimum soil moisture content should range from 50 to 80 percent field capacity (Bossert 1. and R. Bertha). Soil moisture measured at the project site ranged from 60 percent field capacity to the point of saturation (in excess of 100 percent) (Appendix 2). This range falls within and above the optimum content accepted as necessary for microbe population growth. Although it was not necessary to add water to system during this project, the project plan called for no water supplements. Average annual precipitation in Ohio's temperate climate is in excess 100 centimeters $(\mathrm{cm}) 39$ inches (in.) per year. In all but the most extreme drought conditions, natural soil moisture levels should remain at percentages suitable for the successful completion of the bioremediation process. Bioremediation was delayed by high moisture conditions during unseasonably wet weather from November, 1995, through June 1996.

\section{Soil Temperature:}

Soil temperatures below $5^{\circ}$ centigrade $\left({ }^{\circ} \mathrm{C}\right)\left(40\right.$ degrees $\left.\left({ }^{\circ} \mathrm{F}\right)\right)$ retard or stop microbial processes. Soil temperatures above $32^{\circ} \mathrm{C}\left(90^{\circ} \mathrm{F}\right)$ are lethal to many microbes. Ohio's temperate climate, abundant precipitation and soil compositions interact so as to keep soil temperatures far below $32^{\circ} \mathrm{C}\left(90^{\circ} \mathrm{F}\right)$. On the other extreme, lower near surface soil temperature effectively sets the seasonal time-frame in which bioremediation may be utilized without using measures to control the soil temperature. Therefore, no data was gathered during months when near surface 
soil temperatures dropped below $8^{\circ} \mathrm{C}\left(45.7^{\circ} \mathrm{F}\right)$.

\section{Oxygen:}

Microbes which most actively degrade crude oil require oxygen to survive. Oxygen levels were not directly measured or monitored. Sufficient levels of soil aeration were achieved by tilling. Tilling reduced soils to a fine texture with a very high surface area to volume ratio. This enhanced soil aeration and hence the bioremediation process. Tilling also mixed the

petroleum hydrocarbon and soil amendments evenly distributing them throughout the soil. As expected, this enhanced the process by placing more "food" and nutrients in contact with viable microbe colonies.

pH:

Soil $\mathrm{pH}$, or the relative acidity of the soil, also affects microbe population development and therefore the rate at which the process proceeds. Microbe colonies thrive within a fairly narrow $\mathrm{pH}$ range. For this study, $\mathrm{pH}$ was measured on location (Appendix 2) and again in the laboratory.

Initial test plot $\mathrm{pH}$ ranged from just below 5.0 Standard Units (S.U.) to a neutral value of 7.0 S.U. Average $\mathrm{pH}$ was approximately 5.6 S.U. The addition of crude oil alone, had a slight effect on soil $\mathrm{pH}$. Hydrocarbons have many free cations which cause crude oil to have properties of a weak acid. Soils affected by crude oil may be expected to have a lower $\mathrm{pH}$ than similar unaffected soils. Corning grade crude lowered $\mathrm{pH}$ to 5.16 S.U. but Pennsylvania grade crude unexpectedly raised average $\mathrm{pH}$ values to 5.77 S.U. A somewhat unexpected and interesting finding was observed in test plots treated with Pennsylvania grade crude and Clinton oil field brine. Those test plots which received an application of brine, registered higher soil $\mathrm{pH}$ values than plots that did not receive brine. With Pennsylvania crude and brine applied to soil, $\mathrm{pH}$ rose from 5.77 to $6.39 \mathrm{~S}$.U. This has both a positive and negative impact on the process. On one hand, carbonates in brine, working with granular gypsum, buffered soils, thereby raising $\mathrm{pH}$. This elevated $\mathrm{pH}$ quickly approached the optimum 7.0 S.U. goal for the test site. Microbe growth rates and nutrient availability are higher with properly adjusted $\mathrm{pH}$. For this reason, $\mathrm{pH}$ should be measured and adjusted, even if crude oil is the only material in contact with the soil. On the other hand, salts in brine, especially the sodium $(\mathrm{Na}+)$ ion tend to hinder or stop microbe development. The sodium ion also reacts with soils to reduce permeability (Todd ). This leads to saline soils, which do not support plant growth. Fortunately, in temperate climates, the effects of sodium poisoning may be reversed by applying lime, gypsum or other materials rich in calcium or magnesium.

A net excess of granular gypsum was applied to each test plot to raise $\mathrm{pH}$. This caused ion exchange, whereby calcium displaced sodium. This is evidenced by the relatively high calcium ion levels in initial samples. Calcium averaged approximately $1219 \mathrm{mg} / \mathrm{kg}$ in test plots that did not receive brine and $2218 \mathrm{mg} / \mathrm{kg}$ in test plots which received an application of brine. Control 
samples collected on August 17, 1995, averaged $734 \mathrm{mg} / \mathrm{kg}$ of calcium. Carbonates associated with brine caused a net increase in calcium ion levels. Within one month, calcium levels were rapidly decreasing. This is as expected. Calcium ions displaced sodium ions on clay particles and were complexing with other ions. In less than one year, calcium concentrations dropped to an average approximate value of $140 \mathrm{mg} / \mathrm{kg}$ in brine-free plots and $318 \mathrm{mg} / \mathrm{kg}$ in brined plots.

Magnesium levels were initially low relative to calcium. The control sample had 168 $\mathrm{mg} / \mathrm{kg}$ of magnesium. Brine-free test plots averaged approximately $191 \mathrm{mg} / \mathrm{kg}$ while brin treated

plots averaged $217 \mathrm{mg} / \mathrm{kg}$ after the addition of all soil amendments. This indicates brine contributed little to initial magnesium concentrations. Magnesium compounds are generally less soluble, than calcium compounds. This made calcium more available for ion exchange, accounting for the marked decline in calcium ion concentration. At the same time, magnesium compounds were slowly dissociating. With most of the initial ion exchange or complexing complete, magnesium continued to dissociate and sample concentrations increased over time. After one month, magnesium concentrations had no marked increase. After eleven months, concentrations were approximately 12 times higher than initial concentrations.

Results of the chemical analyses indicate lime and to a lesser degree pelletized gypsum, actively exchange ions, and free ions readily recomplex. Granular gypsum adjusts $\mathrm{pH}$ slowly. This slow $\mathrm{pH}$ adjustment rate and greater cost of granular materials, makes use of such materials less desirable for the bioremediation process. This process adjusts $\mathrm{pH}$ and causes ions such as 222 sodium, which may be detrimental to the bioremediation process, to complex and ultimately disperse.

With very few exceptions, $\mathrm{pH}$ adjustment is not a limiting factor when evaluating site remediation options. However, adjustment is necessary to optimize the bioremediation process.

\section{Nutrients:}

Nutrient levels impact the bioremediation process much as they do agriculture. Overapplication of a nutrient, especially an inorganic fertilizer, may at a minimum be an unnecessary expense or may lead to more significant problems. Too much fertilizer may actually slow the remediation process and may lead to surface or ground water contamination. Conversely, low nutrient concentrations may slow microbial activity, in turn greatly slowing beneficial reduction of petroleum hydrocarbons.

Nitrogen, phosphorous and potassium are all important nutrients, but nitrogen levels affect the process most noticeably. Fertilizers with nutrient ratios of 4:1:1 are believed to optimize microbial activity, (Deuel and Holliday) but fertilizers with equal ratios do not seem to have a negative effect. Nutrients are also available through a variety of organic materials. Examples include individually or as a mixture; composted manure, mulch, rotted sawdust and peat. These organic nutrients may also introduce beneficial microbes to the soils. When mixed with soil, these materials increase soil permeability and cause soils to have a finer texture which increases surface 
area and aeration. On the negative side, organics very often lower soil $\mathrm{pH}$ especially when applied in excess. Some combination of inorganic fertilizer and an organic soil amendment may prove most beneficial. Phosphates and potassium are readily adsorbed on soil particles and are not as likely to affect ground water (Todd). Inorganic parameters most likely to affect ground water include chloride, sodium, sulfate and nitrate.

After fertilization, nitrogen, potassium and phosphorus concentrations were markedly lower in the portion of the test area treated with brine. Nitrogen levels ranged from $138 \mathrm{mg} / \mathrm{kg}$ to $1185 \mathrm{mg} / \mathrm{kg}$. The average value in the brine treated soil was $275 \mathrm{mg} / \mathrm{kg}$. The untreated area had an average value of $800 \mathrm{mg} / \mathrm{kg}$. Potassium values ranged from $240 \mathrm{mg} / \mathrm{kg}$ to $1160 \mathrm{mg} / \mathrm{kg}$. Brine treated soils averaged $323 \mathrm{mg} / \mathrm{kg}$ while untreated areas averaged $828 \mathrm{mg} / \mathrm{kg}$. Phosphorus values ranged from $2.6 \mathrm{mg} / \mathrm{kg}$ to $92.8 \mathrm{mg} / \mathrm{kg}$. Brine treated soils average $8 \mathrm{mg} / \mathrm{kg}$ while untreated values averaged $34 \mathrm{mg} / \mathrm{kg}$. The control sample had nitrogen, potassium and phosphorous concentrations of 0,40 and $0 \mathrm{mg} / \mathrm{kg}$ respectively.

The authors conclude that very low inorganic nutrient concentrations in the brine treated areas, even after the application of fertilizer, are the result of complexing with free ions associated with brine. Nitrogen, potassium and phosphorus likely complexed with free ions to form oxides, salts and acids. Nitrogenous compounds are converted into nitrates. The phosphorus compounds are converted to phosphate. Inorganic nutrients are consumed by these chemical reactions. Nutrients, especially nitrogen, are also consumed during microbial degradation of organic matter such as sawdust, manure or crude oil. As a result, after brine has been purged from the system, a second application of fertilizer may be necessary. To avoid this, $\mathrm{pH}$ adjustment material (i.e. powdered lime) should be applied and rotary tilled into the soils. When salt concentrations have been sufficiently reduced, fertilizer may then be more effectively tilled into soils. Fertilizer and lime may be applied at the same time in areas unaffected by brine.

A carbon to nitrogen ratio of 150 to 1 is recommended for the bioremediation process. (Deuel, 1994) This ration may be calculated using the following formula:

$\%$ TPH X 0.78 X 10,000 = carbon $(\mathrm{ppm})$

Simply put, fertilizers should be applied at a rate equaling 150 parts TPH to one part nitrogen. Control sample concentrations of nitrogen were below detection limits, or in essence zero. The introduction of nitrogen was critical for this bioremediation project. When possible, nitrogen levels should be four times greater than phosphate and potash values. Again, a fertilizer with a 4.1:1 ratio is ideal, but other fertilizer ratios do not seem to adversely affect the process.

\section{Electrical Conductance:}

Electrical conductance (EC) of soils was analyzed as a reference or standard by which relative salinity could be measured. EC testing may be used to show that brine associated with crude oil does contribute to an overall increase in conductivity. However, the volume of bine associated with crude oil is sufficiently low, therefore, there will generally be a low salinity hazard to plants and microbes. 
Test plots which received approximately 6 liters $/$ meter $^{2}\left(0.13\right.$ gal./ft. ${ }^{2}$ ) (or about a pint per square foot) of brine did have salt concentrations increased to a level which would cause a moderate salinity hazard for plants and microbes (Todd). The brine application rate was considered analogous to a tank rupture with the contents flowing over the lands surface. Spills with puddled brine which soaks into soil or continuous leaks overtime, would likely cause much higher salt concentrations in soil. Crude oil spills with associated brine spills must be treated in a manner different than procedures for simple crude oil spills.

As expected, electrical conductivity values were higher in plots receiving brine. Interestingly, soils which were not directly affected by brine also demonstrated elevated EC values. EC values in plots receiving direct brine application averaged approximately 281 micromhos per centimeter (umhos/cm) (corrected to 25 degrees C) while untreated plots averaged 139 umhos/cm. It is believed crude oils were intermixed with enough brine to cause EC levels to be elevated over the entire project site. As a point of reference, EC values less than 250 (umhos/cm) are indicative of soils which have low salinity hazards to plants (Richards, 1954 from Todd). This test provides a very good point of reference to evaluate the presence of brine during the bioremediation process.

\section{Salinity:}

Ohio brines produced from deeper formations often have chloride concentrations in excess of $180,000 \mathrm{mg} / \mathrm{l}$. Brine composition is predominantly sodium chloride. Elevated levels of carbonates, sulfates and oxides are also present. Therefore, test plots treated with brine had very high sodium concentrations. Brine-free test plots had averaged sodium concentrations of approximately $206 \mathrm{mg} / \mathrm{kg}$ while brine treated plots averaged approximately $1877 \mathrm{mg} / \mathrm{kg}$. Control soil samples averaged approximately $65 \mathrm{mg} / \mathrm{kg}$ of sodium.

Two months after the application of granular gypsum, sodium concentrations in brine treated plots were greatly reduced. At this time, sodium averaged approximately $441 \mathrm{mg} / \mathrm{kg}$. Sodium concentration were still twice as high as brine-free test plots, but these concentrations were 70 to $80 \%$ less than initial concentrations. Several factors likely contributed to this rapid and substantial reduction in sodium. High soil moisture levels caused dilution and allowed some brine to be leached away. Some sodium complexed and some was adsorbed by clay particles. Over the following nine months, calcium displaced most of the sodium.

The chloride ion has a weaker ionic bond than the sodium and does not attach to other cations as readily as sodium does to other anions. In the dissociated state, the ion remains relatively mobile and is more likely to be purged from the system. The chloride ion also has less affect on microbe or flora development than sodium.

Field tests or laboratory analyses for chloride are useful in determining the relative concentration of brine, or more properly, sodium chloride (salt) in the soil. To counter the negative effects of brine, $\mathrm{pH}$ buffer materials should be in a form which releases cations (Calcium and Magnesium) as quickly as possible. Rapid ion exchange is best achieved using very finely 
ground lime or gypsum or through the application of powdered or liquid $\mathrm{pH}$ adjusters, such as calcium oxide. The granular or pelletized gypsum initially used in this study released calcium and magnesium too slowly to effectively adjust soil $\mathrm{pH}$.

\section{Total Petroleum Hydrocarbons (TPH):}

Total Petroleum Hydrocarbons were evaluated to determine the relative concentration of petroleum in soil. TPH may be recorded as $\mathrm{mg} / \mathrm{kg}$, ppm or as a relative percentage of the total sample. TPH analyses are of chemically undifferentiated hydrocarbons with the total value equaling the sum of all individual component values.

Initial hydrocarbon values establish the baseline or "starting point" for a bioremediation project. Intermediate samples may be collected and analyzed to determine the degree or efficiency of microbial reduction of hydrocarbons. Although intermediate samples were collected for this study, they may not be necessary for every remediation project. Simple observations of affected soil often allow for a generalized determination of project effectiveness. Relative strength of hydrocarbon odor and degree of discoloration or staining of soil are very effective efficiency indicators. But to be sure microbial processes have run their course and hydrocarbons have been reduced to harmless by-products, a final or closure TPH sample must be collected and analyzed.

For this study, a Pennsylvania crude (43 API gravity) and a Corning crude (34 API gravity) were used in an effort to determine the effect of crude oil grade and gravity on the bioremediation process. Background or control samples for Total Organic Carbon (TOC) were collected on August 17, 1995, prior to the application of crude oil, brine or soil amendments. TOC analyses were selected rather than TPH in an effort to determine organic content of soil which is not related to the application of crude oil. After the application of crude oil, TPH analyses were utilized to determine relative organic carbon concentrations of crude oil in the soil.

Before soil amendments were added to the system, Pennsylvania crude was analyzed in soil samples at an initial concentration of $32,300 \mathrm{mg} / \mathrm{kg}$ or about $3.2 \% \mathrm{TPH}$, and Corning grade crude was $18,800 \mathrm{mg} / \mathrm{kg}$ or about $1.9 \% \mathrm{TPH}$. Only Pennsylvania crude was utilized in the brine treated areas. In brine-treated plots, TPH concentrations in soil samples were $11,100 \mathrm{mg} / \mathrm{kg}$ or about $1.1 \%$ TPH. Although equal volumes of crude was applied to each test plot, it appeared initial concentrations were quite varied. This is the result of varied mixing by tilling and inherent sampling variability of soils.

After approximately one month, TPH values in soil samples reduced to an average of approximately $6900 \mathrm{mg} / \mathrm{kg}$ or about $0.7 \%$. Soils treated with Pennsylvania crude averaged approximately $9000 \mathrm{mg} / \mathrm{kg}$ or approximately $0.9 \%$ which is a reduction of TPH from $3.2 \%$ when compared to initial samples. Those treated with Corning crude averaged approximately 4800 $\mathrm{mg} / \mathrm{kg}$ or approximately $0.5 \%$. Individual TPH values fluctuated greatly, but in every case, TPH values of soil with Pennsylvania crude were higher than that of those with Corning crude in 
corresponding test plots. This was initially believed to be the result of incomplete mixing with soil which then impacted composite samples. Frequency of tilling and number of composite samples within each plot was increased. The second or intermediate samples varied in concentration but trends or relative concentrations closely matched initial TPH sample results. Intermediate TPH values averaged approximately $6800 \mathrm{mg} / \mathrm{kg}$ or $0.7 \%$. Pennsylvania crude averaged approximately $7300 \mathrm{mg} / \mathrm{kg}$ or $0.7 \%$. The project averaged TPH values from initial sampling closely matched values from intermediate sampling. Although averaged intermediate TPH values for Pennsylvania and Corning crude oils differed from initial values, relative ratios were unchanged. TPH values for Pennsylvania crude was consistently higher than Corning TPH values.

Initial and intermediate TPH results indicate thorough tilling and extensive composite sampling are necessary for accurate values. In addition, grade of crude oil, or more accurately, crude oil composition does have an effect on TPH values. Crude oils having higher specific gravities tend to have a greater concentration of light end or volatile components. Light end compounds tend to volatilize quickly and are among the earliest of chemicals to be consumed in the bioremediation process. Beyond light end fractions, the two crude oils have a very similar chemical composition with very similar concentrations of individual components.

The final set of TPH data was collected approximately 11 months after the project was initiated. Each test plot was sampled twice with each sample consisting of five individual or composite samples. Laboratory results indicate TPH concentrations were less than the test method and calibration detection limit in every test plot. This suggests microbial degradation of the crude oil was complete.

Betx:

To determine the extent of crude oil degradation, values for some of the most volatile components, Benzene, Toluene, Ethylbenzene and Xylene were compared. Light end, more volatile hydrocarbons are often used as indicators to determine the relative age or "freshness" of a contamination event. When contamination of soil or water is suspected, regulatory agencies usually test for four common hydrocarbon compounds. These compounds are benzene, toluene, ethylbenzene and xylene. Collectively, the four compounds are referenced as BTEX compounds.

BTEX compounds were analyzed during the course of this study. Benzene (Betx) was below the method and equipment detection limit in all plots during initial sampling. This would indicate benzene had either volatilized very quickly or concentrations in the crude oil were very low. Crude oil analyses (Appendix 9) do not indicate the presence of benzene although several benzene derivatives are present in very low concentrations. Closure samples also indicate benzene concentrations, for every test plot, were below detection limit. It would appear that if benzene is present in these crude oils, it is present in small quantities and would seem to volatilize very quickly.

Toluene (bTex) concentrations in Pennsylvania crude were equivalent to $0.00246 \%$ of the total crude oil weight. Using the highest concentration in the soil, toluene equals $0.00053 \%$ of 
the total soil sample weight. One year after these initial results, closure samples indicate toluene is no longer detectable in the system. In every test plot, toluene was below detection limits. The presence of toluene is arguable, but minute concentrations originally reported are not present at closure. Toluene is readily degraded through microbial processes. This compound is also very volatile. It is believed both processes have contributed to elimination of this compound from the system.

Ethylbenzene (btEx) was not detected in most initial soil samples but concentrations ranging up to $78.2 \mathrm{ug} / \mathrm{kg}$, with an approximate average value of $21.0 \mathrm{ug} / \mathrm{kg}$ were detected in some samples. This compound was not detected in Corning grade crude but was present with a concentration of $180 \mathrm{mg} / \mathrm{kg}$ in Pennsylvania grade crude. Once again, Corning grade crude seems to lack or have lower concentrations of lighter, more volatile components, such as ethylbenzene. Closure samples from every test plot indicate concentrations of ethylbenzene are less than the detection limit.

Xylene (bteX) is generally reported as a value representing the total concentration for all isomers. Initial concentrations of xylene in soil samples ranged from up to $783 \mathrm{ug} / \mathrm{kg}$ with an approximate average concentration of $118.3 \mathrm{ug} / \mathrm{kg}$. Xylene was present in both crude oils, but unlike benzene, toluene or ethylbenzene, concentrations were greater in Corning rather than Pennsylvania crude. Specific concentrations in either crude oil may only be estimated because the isomers volatilize with other compounds and were not differentiated for this study. Closure samples from all test plots indicate xylene concentrations are below the method detection limit.

Crude oils used in this project were held in storage tanks for a relatively short period. During production and handling, BTEX and similar compounds are likely to volatilize. This may result in BTEX values which are lower than values collected in a closed system. Stored crude was selected rather than crude collected directly from a wellhead or production line. This allowed for better control of crude to brine ratios so the affects of brine could be more accurately monitored. This also more closely approximated spills originating from storage or gathering facilities. Spills may be associated with the wellhead, gathering lines or separator, but these spills are generally localized and tend to be lower in volume.

\section{Metals:}

Heavy metals were monitored through the course of this study. These metals have a tendency to complex and are not easily purged from a system. If present in certain chemical form and in elevated concentrations, heavy metals may have a toxic affect. Certain heavy metals may occur naturally in soils while others may be introduced.

Background or control soil samples for heavy metals were analyzed by Toxicity Characteristic Leaching Procedure Waste Characterization (TCLP) extraction method. This test method is commonly used by regulatory agencies to detect metals which are present in a chemical form that may be leached or extracted from soil (media). Metals tested include, arsenic, barium, cadmium, chromium, lead, mercury, selenium and silver. Barium, lead and selenium were 
detected in the control sample in concentrations of $1.4 \mathrm{mg} / 1,0.005 \mathrm{mg} / \mathrm{l}$ and $0.012 \mathrm{mg} / \mathrm{l}$ respectively. Possible soil contaminant sources were evaluated. Historically, heavy equipment, machinery and supplies may have been stored in this general area. In addition, paint over spray, possibly lead based, may have had the potential of drifting to this site. Dust from an equipment maintenance yard, small airport and a township road may have also reached the study area.

Barium compounds are not uncommon in Ohio soils, especially in the glaciated portion of the state. It is likely barium detected in the control sample is the result of an isolated naturally occurring barium mineral contained in glaciated soil. The majority of barium compounds found in these soils are oxidized and are only slightly soluble in water. TCLP extraction utilizes an adjusted $\mathrm{pH}$ which may cause certain barium compounds to go into solution. Initial soil samples with Pennsylvania crude, Corning crude and with a combination of Pennsylvania crude and Clinton formation brines do not indicate the presence of barium. Barium was only detected in the initial control sample.

As mentioned earlier, lead was present in the control sample. It was also present in initial samples of soil with Penn, Corning and Penn/Brine. Samples collected during the study indicate concentrations are slightly less than that of control sample analysis. Concentrations of lead in site closure samples reflect values lower than that of control sample in every test plot. Many of the test plots had lead concentrations that were a factor of 10 lower than the control sample. Background soil samples collected on August 17, 1995 show 0.005 mg/l. lead . Other samples collected on this date included soils with Pennsylvania crude, Corning crude and Pennsylvania crude with Clinton formation brine. Lead concentrations were $0.002,0.004$ and $0.002 \mathrm{mg} / \mathrm{l}$ respectively. Lead concentrations were lower toward the end of the project. The lowered concentrations per volume of soil are thought to be caused by mixing with soils by tilling rather than through a chemical reduction. Lead is still present, but when thoroughly mixed with soils, overall concentrations per unit of soil are lowered. In other words, thorough tilling caused a "dilution" of detectable lead. In essence, the brine and crude oil had no impact on lead concentrations in this study.

Selenium is also present in many soils. It is often present in sulfide ores of heavy metals and is found in small quantities in pyrite. This metal is also used as a catalyst in determination of nitrogen by Kjeldahl method, therefore has the potential to be a laboratory contaminant (Merck Index). Concentrations in initial soil samples with Pennsylvania and Corning crude and Pennsylvania crude with Clinton brine are slightly greater than control soil results. This suggests both brine and crude oil have very low concentrations of selenium which may contribute to the overall ion concentration. Grade of crude seemed to have no affect on selenium concentrations. Intermediate samples have selenium concentrations that approximate both control and initial concentrations. Closure samples seem to be somewhat of an anomaly. Selenium was below the method detection limit in every test plot. It would then seem that selenium has either disassociated and been purged from the system or has recomplexed to form stable insoluble compounds. In either case, only trace amounts of selenium were originally detected. These low concentrations do not affect the bioremediation process nor do they affect site closure. 
Several metals were not present in the control sample but were detected in samples during the course of this project. Arsenic was not present in the control sample to initial samples with crude oil, but was present in the initial sample with brine. The concentration in this sample, 0.007 $\mathrm{mg} / \mathrm{kg}$, approximated the average concentration in intermediate samples. It should be noted that arsenic was not detected in every test plot and does not appear to have any correlation to the application of brine, crude oil or various soil amendments. When detected, concentrations were significantly lower than "averaged" concentrations in the earths crust $(0.0005 \%$ or $5 \mathrm{ppm})$ (Merck Index,).

Mercury was not detected in control or background samples, but was present in some intermediate and closure samples. When detected, concentrations were extremely low with no apparent correlation with crude oil, brine or soil amendments. Mercury has an "averaged" abundance of $0.5 \mathrm{ppm}(0.00005 \%)$ in the earth's crust (Merck Index). This "averaged" concentration is approximately 100 times greater than concentrations in the plots.

Silver was only detected in four test plots and only in the site closure samples. Concentrations were very near the method detection limit. Concentrations of silver in the earth's crust have an "averaged" value of $0.1 \mathrm{ppm}$ (Merck Index). Concentrations in this study averaged slightly less than $0.04 \mathrm{ppm}$. Again, there is no apparent correlation between the silver concentration and application of crude, brine or soil amendments.

Arsenic, mercury and silver may be present in typical crudes or deep formation brine. If present, these metals appear to have very low concentrations which approach method detection limits. Reliability of test results which are at or very near method detection limits becomes questionable. In most cases, concentrations were less than "averaged" concentrations in the earth's crust.

None of the TCLP metals detected during the course of this study appear to be present in concentrations that may adversely affect the bioremediation process. On the other hand, metals do tend to accumulate in soils. Sites subjected to repeated application of contaminants, such as a centralized commercial facility, should be monitored for such metals. Although it may not be necessary to analyze for heavy metals by TCLP extraction, this test, with proper control samples, may minimize liability. Pre-existing contamination by certain heavy metals may also affect the level and type of remediation utilized at a given site. 


\section{Summary}

The bioremediation of petroleum hydrocarbon contaminated materials has been studied for decades. In recent years, many scientific studies have focused on this process. Indeed, a new industry has evolved around the genetic engineering of microbes for specific hydrocarbons and specific environments. The authors have reviewed many recent studies to evaluate the bioremediation process as a method to correct contamination problems within Ohio's oil and gas industry. This study was intended to evaluate the overall effectiveness of the bioremediation process in Ohio's temperate climate. Petroleum hydrocarbons that are characteristic for this region of the Appalachian Basin were utilized. Some of the major factors or variables affecting this process were observed and even altered. Scientific data was collected through the course of the study. The data was then used with the many recorded observations and practical considerations to determine if this very technical process could be utilized as a remediation tool in Ohio's waste management hierarchy. It is known that this process works in the laboratory and in the field under the close watch of a properly trained and technically competent work force. This is good news, but it is also perceived as a technical and cost limiting factor in its use. One of the more important aspects of this study included an evaluation of the process in a nontechnical approach. Inexpensive, readily available materials were utilized. Soil temperature and moisture levels were monitored, but not controlled, and no commercial microbe cultures were introduced to the system. Focus was also placed on proper spill characterization and documentation, evaluation of environmental, hydrologic and geologic conditions and creating a guideline to streamline the testing and review processes.

Results of this study indicate the bioremediation process is an effective method for site remediation of petroleum hydrocarbon contaminated soils in certain settings. Through this study, the Division has developed a non-technical users manual to be used by industry and Division staff. An evaluation matrix addressing certain legal, environmental, hydrologic, geologic and economic factors may be utilized by industry to determine if this process is appropriate for a given site and

event. A regulatory review process has been established to efficiently process and review industry requests to use bioremediation on a specific site. Testing methods and closure limits have also been established.

The Division will include bioremediation in the waste management hierarchy. Further, Division staff will present the results of this study in two bioremediation workshops during 1997. This study has proved to be quite beneficial to the states waste management programs. 


\section{REFERENCES}

Bossert, I. and R. Bartha. 1984. The Fate of Petroleum in Soil Ecosystems in Petroleum Microbiology. Atlas, Rl M. Led, Macmillan Publishing Company, New York.

Brady, N. C. 1990. The Nature and Properties of Soils. Macmillan Publishing Company, New York, NY.

Budavari, Susan, Et Al. 1989. The Merck Index, An Encyclopedia of Chemicals, Drugs and Biologicals. Eleventh edition. Merck and Co., Inc., Rahway, NJ.

Calabrese, Edward J. and Paul T. Kostecki. 1993. Principles and Practices for Petroleum, Contaminated Soils. Lewis Publishers, Chelsea, MI.

Deuel L. E. and G. H. Holliday. 1994. Soil Remediation for the Petroleum Extraction Industry. Pennwell Publishing Company

Freeze, Allan R. and John A. Cherry. 1979. Groundwater. Prentice - Hall Inc., Englewood Cliffs, New Jersey.

Gilius, Ronald P. and John S. Wetherell and Stephen J. Grimme. 1994. Characterization and Disposal Options for Oilfield Wasted in Pennsylvania. Commonwealth of Pennsylvania, Department of Environmental Resources, Bureau of Oil and Gas Management.

Interstate Oil and Gas Compact Commission Guidelines for State Oil and Gas Regulatory Programs May 1994., IOGCC, Oklahoma City, Oklahoma.

Interstate Oil and Gas Compact CommissionlU.S. Environmental Protection Agency State Review of Oil and Gas Exploration and Production Waste Management Regulatory Programs, Ohio State Review, May 1995., IOGCC, Oklahoma City, Oklahoma.

Lessig, Heber D., Et Al. 1971. Soil Survey of Mahoning County, Ohio. United States Department of Agriculture, Soil Conservation Service.

Nugent, James E. and Mary Scott Nabers and Barry Williamson. 1994. Waste Minimization 
in the Oil Field. Railroad Commission of Texas. Oil and Gas Division.

Ohio Department of Natural Resources, Division of Oil and Gas. 1996. Annual Report.

Sparks, Donald L. 1995. Environmental Soil Chemistry. Academic Press Inc., San Diego, CA

Todd, David Keith. 1980. Groundwater Hydrology. 2nd Ed. John Wiley and Sons, New York.

Walton, Hohn C. 1970. Groundwater Resource Evaluation. McGraw-Hill Book Company, New York.

US Environmental Protection Agency, Health Effects Assessment Summary Table, April 4, 1991

US Environmental Protection Agency, 40 CFR Part 261 Identification and Listing of Hazardous Wastes, June 29, 1990. 